\title{
Elastic Modulus Measurement of ORNL ATF FeCrAl Alloys
}

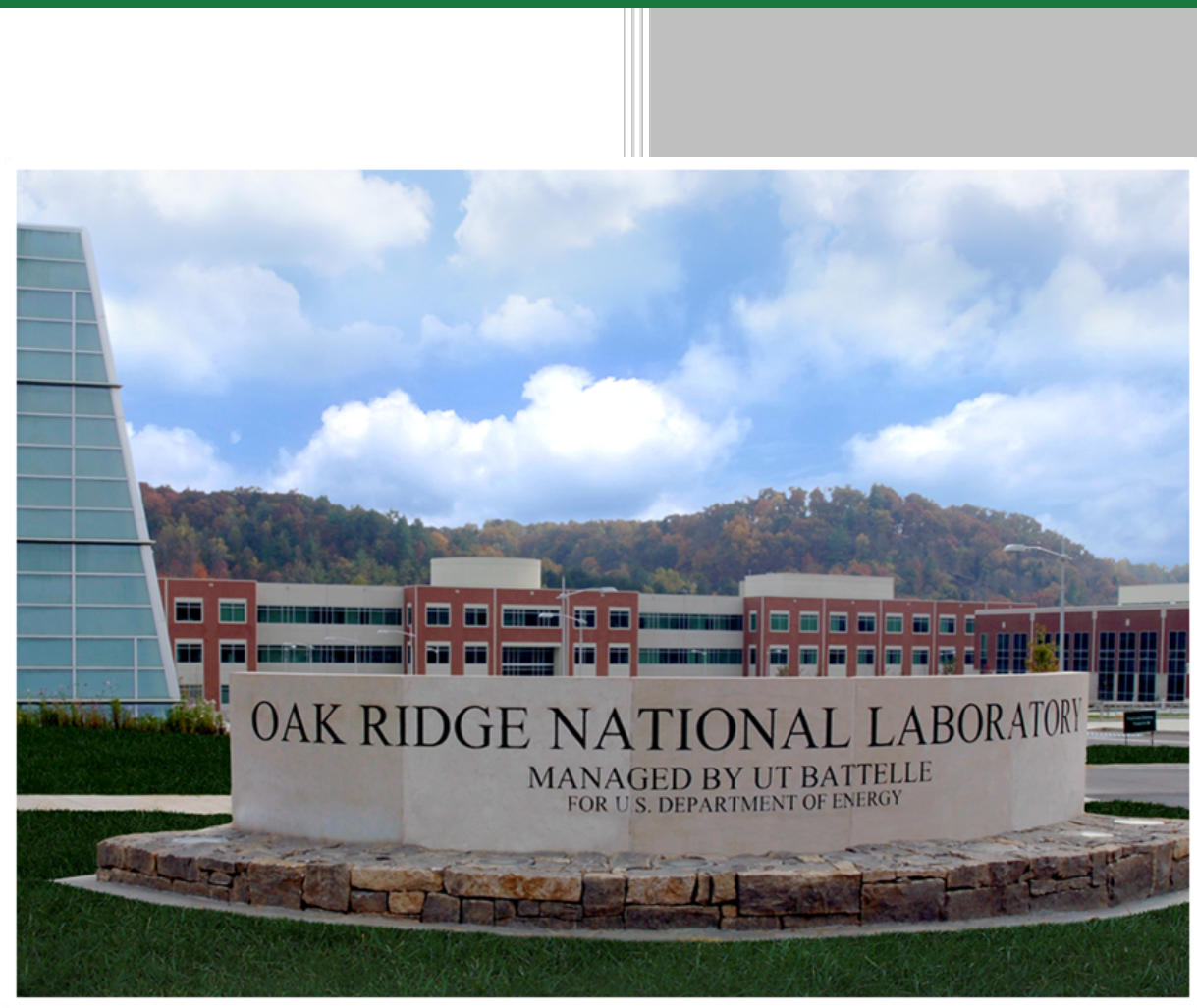

Approved for public release; distribution is unlimited

Z. T. Thompson

K. A. Terrani

Y. Yamamoto

October, 2015 


\section{DOCUMENT AVAILABILITY}

Reports produced after January 1, 1996, are generally available free via US Department of Energy (DOE) SciTech Connect.

Website http://www.osti.gov/scitech/

Reports produced before January 1, 1996, may be purchased by members of the public from the following source:

National Technical Information Service

5285 Port Royal Road

Springfield, VA 22161

Telephone 703-605-6000 (1-800-553-6847)

TDD 703-487-4639

Fax 703-605-6900

E-mail info@ntis.gov

Website http://www.ntis.gov/help/ordermethods.aspx

Reports are available to DOE employees, DOE contractors, Energy Technology Data Exchange representatives, and International Nuclear Information System representatives from the following source:

Office of Scientific and Technical Information

PO Box 62

Oak Ridge, TN 37831

Telephone 865-576-8401

Fax 865-576-5728

E-mail reports@osti.gov

Website http://www.osti.gov/contact.html

This report was prepared as an account of work sponsored by an
agency of the United States Government. Neither the United States
Government nor any agency thereof, nor any of their employees,
makes any warranty, express or implied, or assumes any legal liability
or responsibility for the accuracy, completeness, or usefulness of any
information, apparatus, product, or process disclosed, or represents
that its use would not infringe privately owned rights. Reference herein
to any specific commercial product, process, or service by trade name,
trademark, manufacturer, or otherwise, does not necessarily constitute
or imply its endorsement, recommendation, or favoring by the United
States Government or any agency thereof. The views and opinions of
authors expressed herein do not necessarily state or reflect those of
the United States Government or any agency thereof.


Fuel Cycle Research and Development

\title{
ELASTIC MODULUS MEASUREMENT OF ORNL ATF FeCrAI ALLOYS
}

\author{
Z. T. Thompson \\ K. A. Terrani \\ Y. Yamamoto
}

October, 2015

\author{
Prepared by \\ OAK RIDGE NATIONAL LABORATORY \\ Oak Ridge, TN 37831-6283 \\ managed by \\ UT-BATTELLE, LLC \\ for the \\ US DEPARTMENT OF ENERGY \\ under contract DE-AC05-00OR22725
}





\section{CONTENTS}

CONTENTS

Appendix A: Measured Elastic and Shear Moduli, Poisson's Ratio, and Associated Error for

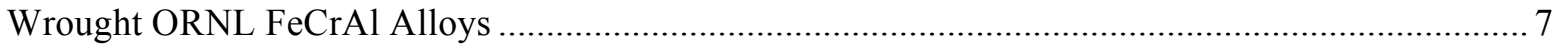





\section{LIST OF FIGURES}

Figure

Page

Figure 1. Elastic moduli of the various ORNL wrought FeCrAl alloys as a function of temperature, compared to Zircaloy [4], PM2000 [5], and AMPT [6] 3

Figure 2. Poisson's ratio of the various ORNL wrought $\mathrm{FeCrAl}$ alloys as a function of temperature.

\section{LIST OF TABLES}

Table

Page

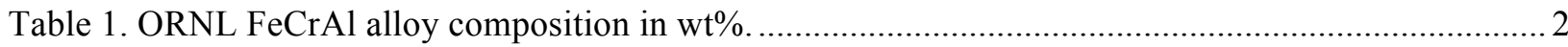





\title{
ACKNOWLEDGEMENTS
}

The aid and technical insight of Amit Shyam and Dana McClurg is gratefully acknowledged. The work presented in this paper was supported partially by the Advanced Fuels Campaign of the Fuel Cycle R\&D program in the Office of Nuclear Energy, U.S. Department of Energy as well as by Laboratory Directed R\&D funds at ORNL. Science Undergraduate Laboratory Internships also lent financial support for the internship utilized during this study.

\begin{abstract}
Elastic modulus and Poisson's ratio for a number of wrought FeCrAl alloys, intended for accident tolerant fuel cladding application, are determined via resonant ultrasonic spectroscopy. The results are reported as a function of temperature from room temperature to $850^{\circ} \mathrm{C}$. The wrought alloys were in the fully annealed and unirradiated state. The elastic modulus for the wrought $\mathrm{FeCrAl}$ alloys is at least twice that of $\mathrm{Zr}$-based alloys over the temperature range of this study. The Poisson's ratio of the alloys was 0.28 on average and increased very slightly with increasing temperature.
\end{abstract}

\section{INTRODUCTION}

FeCrAl alloys have been proposed as accident tolerant fuel cladding concepts to replace Zr-based alloys in light water reactors [1]. One of the aspects of the viability of these cladding materials that needs to be assessed is their thermo-mechanical performance under normal operating conditions. This assessment can be carried out effectively using fuel performance analysis codes assuming detailed and accurate temperature- and dose-dependent material property data are available. Therefore accurate material property information is necessary that needs to be obtained using well-controlled experiments on applicable materials.

One important input into fuel performance analysis tools is the elastic modulus of the cladding. This study aims to provide accurate data on the elastic modulus of $\mathrm{FeCrAl}$ cladding as a function of temperature. Although there is information available in the literature regarding a number of commercial alloys, this study specifically examines nuclear-grade alloys under development at ORNL [2]. 


\section{EXPERIMENT APPROACH}

Resonant ultrasound spectroscopy (RUS) [3] was used to determine, for several FeCrAl alloys, Young's modulus and Poisson's ratio as a function of temperature. The experiments were performed at room temperature and at several other temperatures up to $850^{\circ} \mathrm{C}$. Additional measurements were also made as the samples cooled from $850^{\circ} \mathrm{C}$ to room temperature to investigate any possible effect of heating on microstructure that might lead to a change in the elastic modulus. The tests were carried out on six different alloys, produced at ORNL [2], with the compositions specified in Table 1. The alloys were all in the fully annealed condition $\left(\mathrm{T}<700^{\circ} \mathrm{C}\right)$.

FeCrAl alloy disk specimens, $15 \mathrm{~mm}$ in diameter and between $1.2 \mathrm{~mm}$ and $2.0 \mathrm{~mm}$ in height, were prepared from plates by electrical discharge machining using a Robocut $\alpha$-oiA machine with a Fanuc Series $18 \mathrm{i}-\mathrm{W}$ controlling unit. To remove the oxide layer and produce flat specimens, a table grinder was used to achieve flatness of $\pm 0.6 \%$ of the average height. This is important since a well-known and flat geometry is critical for reliable analysis of RUS data. The disks initially underwent room temperature scans on a Quasar RUSPEC. The spectra were viewed using Galaxy software and the elastic moduli were calculated from the spectrum peaks and density using CylModel v2.68b software. For high temperature testing, the RUS probes and sample were placed inside a furnace that was purged of oxygen. Ar with $<10$ ppb of $\mathrm{O}_{2},<20 \mathrm{ppb}$ of $\mathrm{H}_{2} \mathrm{O},<100 \mathrm{ppb}$ of THC, and $<5 \mathrm{ppm}$ of $\mathrm{N}_{2}$ was cycled through the system during testing. The furnace started at room temperature (around $22{ }^{\circ} \mathrm{C}$ ) and ramped up to $50{ }^{\circ} \mathrm{C}$ at a rate of $3{ }^{\circ} \mathrm{C} /$ min. It then soaked at $50{ }^{\circ} \mathrm{C}$ for $20 \mathrm{~min}$. After that, the furnace ramped up at a rate of $3{ }^{\circ} \mathrm{C} / \mathrm{min}$ stopping every $50^{\circ} \mathrm{C}$ for $20 \mathrm{~min}$ up to $850^{\circ} \mathrm{C}$. The furnace then cooled back down to room temperature at a rate of $3{ }^{\circ} \mathrm{C} / \mathrm{min}$ stopping every $50{ }^{\circ} \mathrm{C}$ until it reached $100^{\circ} \mathrm{C}$. At this point the furnace was turned off allowing the sample in the furnace to cool down to about $60^{\circ} \mathrm{C}$ and then air cool back to room temperature. Scans were taken at initial and final room temperatures and at $100{ }^{\circ} \mathrm{C}, 200^{\circ} \mathrm{C}, 300{ }^{\circ} \mathrm{C}, \ldots, 800{ }^{\circ} \mathrm{C}$, and $850{ }^{\circ} \mathrm{C}$ while heating and $700{ }^{\circ} \mathrm{C}, 500{ }^{\circ} \mathrm{C}, 400{ }^{\circ} \mathrm{C}, 300{ }^{\circ} \mathrm{C}, 200{ }^{\circ} \mathrm{C}$, and $100{ }^{\circ} \mathrm{C}$ while cooling. The scans were initiated by Universe software after 10 min once soaking began and saved by Galaxy software. Each spectrum was later fit and the elastic moduli calculated using CylModel v2.68b software.

Table 1. ORNL FeCrAl alloy composition in wt\%.

\begin{tabular}{|l|c|c|c|c|c|c|c|c|c|c|c|c|}
\hline Alloy ID & Fe & Cr & Al & Y & Mo & Si & Nb & C & S & O & N & P \\
\hline B106Y & 83.98 & 10.06 & 5.93 & 0.003 & $<0.01$ & $<0.01$ & $<0.01$ & 0.0040 & 0.0028 & 0.0118 & 0.0015 & $<0.002$ \\
\hline T35Y & 82.26 & 13.18 & 4.44 & 0.07 & $<0.01$ & 0.01 & $<0.01$ & 0.0040 & 0.0009 & 0.0022 & 0.0026 & 0.009 \\
\hline B136Y & 80.85 & 12.99 & 6.14 & 0.003 & $<0.01$ & $<0.01$ & $<0.01$ & 0.0030 & 0.0020 & 0.0014 & 0.0005 & $<0.002$ \\
\hline C35M3 & 79.43 & 13.06 & 5.31 & 0.053 & 2 & 0.13 & $<0.01$ & 0.001 & $<0.0003$ & 0.0012 & 0.0003 & 0.007 \\
\hline C36M2 & 78.4 & 13 & 6.29 & 0.059 & 1.99 & 0.2 & $<0.01$ & 0.001 & $<0.0003$ & 0.001 & 0.0004 & 0.004 \\
\hline B166Y & 77.86 & 16.06 & 6.06 & 0.003 & $<0.01$ & $<0.01$ & $<0.01$ & 0.0030 & 0.0023 & 0.0014 & 0.0004 & $<0.002$ \\
\hline
\end{tabular}

\section{RESULTS AND DISCUSSION}

Elastic moduli of the various ORNL FeCrAl alloys examined in this study are plotted in Figure 1 as a function of temperature. Also, for the sake of comparison, the elastic modulus of Zircaloy as well as two dispersion strengthened $\mathrm{FeCrAl}$ alloys are included in the figure. Note that the wrought $\mathrm{FeCrAl}$ alloys exhibit an elastic modulus $2.1 \times$ greater than Zr-based alloys at RT. This ratio monotonically increases to 2.7 at $850^{\circ} \mathrm{C}$. Though some variation is observed among the data for the various wrought alloys, no significant difference between the moduli of the alloys as a function of major alloying elements $(\mathrm{Cr}$ and 
$\mathrm{Al})$ is noted. The $\mathrm{C}$ series alloys that contain $2 \mathrm{wt} \%$ Mo appear to have a slightly higher elastic modulus. In any case, these small variations may be neglected and an overall polynomial fit to the modulus data as a function of temperature can be produced, as shown in Eq. (1).

$$
E=-5.46 \times 10^{-5} T^{2}-3.85 \times 10^{-2} T+1.99 \times 10^{2}
$$

where $\mathrm{E}$ is the elastic modulus in $\mathrm{GPa}$ and $\mathrm{T}$ is temperature in ${ }^{\circ} \mathrm{C}$.

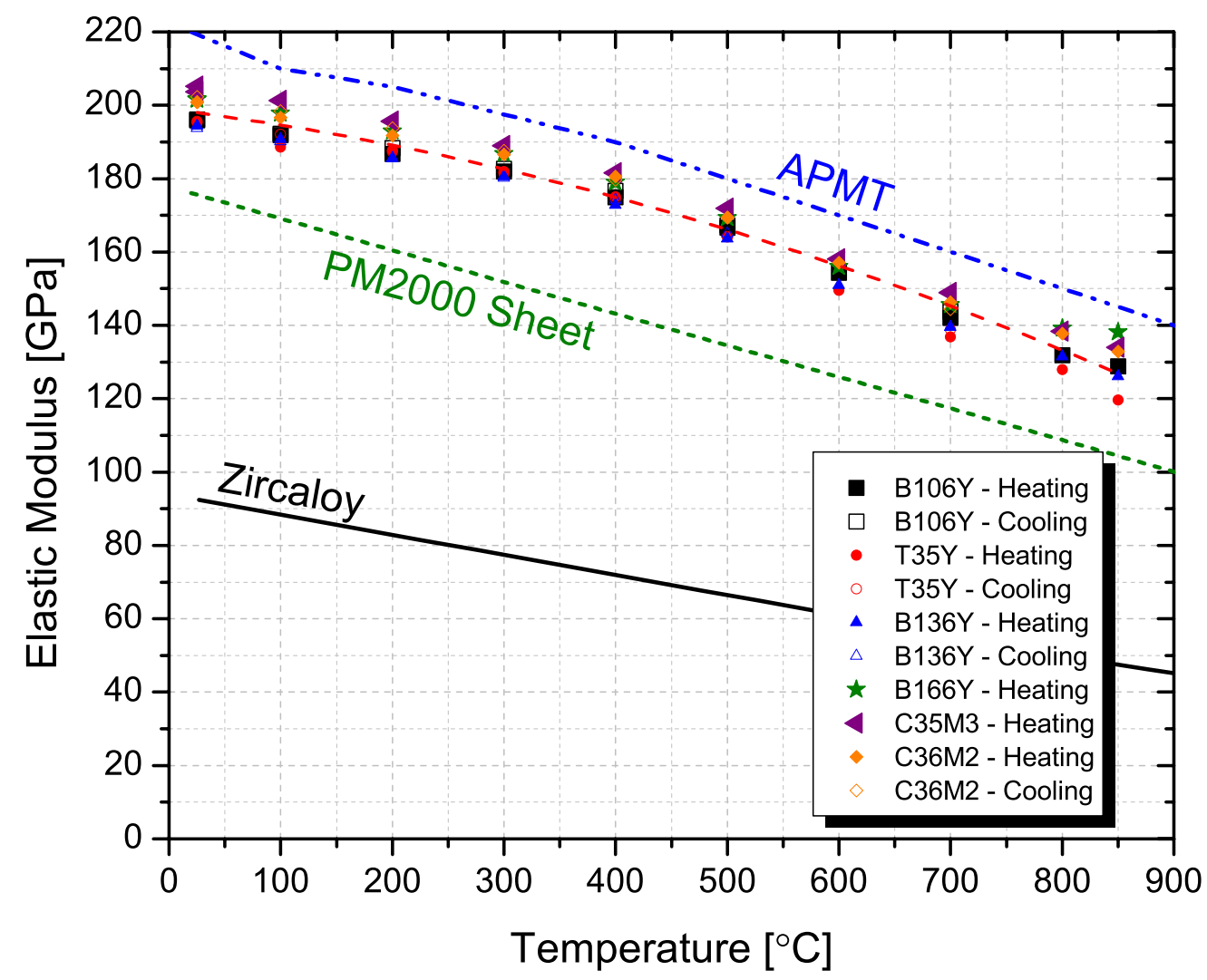

Figure 1. Elastic moduli of the various ORNL wrought FeCrAl alloys as a function of temperature, compared to Zircaloy [4], PM2000 [5], and AMPT [6].

Figure 2 shows the value of Poisson's ratio for the various ORNL wrought FeCrAl alloys as a function of temperature. Again, no major trend as a function of major alloying elements is observed in this dataset. The Poisson's ratio for all the alloys increases slightly with increasing temperature; this trend is approximated with a linear fit from room temperature to $700^{\circ} \mathrm{C}$ :

$$
v=3.85 \times 10^{-5} T+2.68 \times 10^{-1}
$$




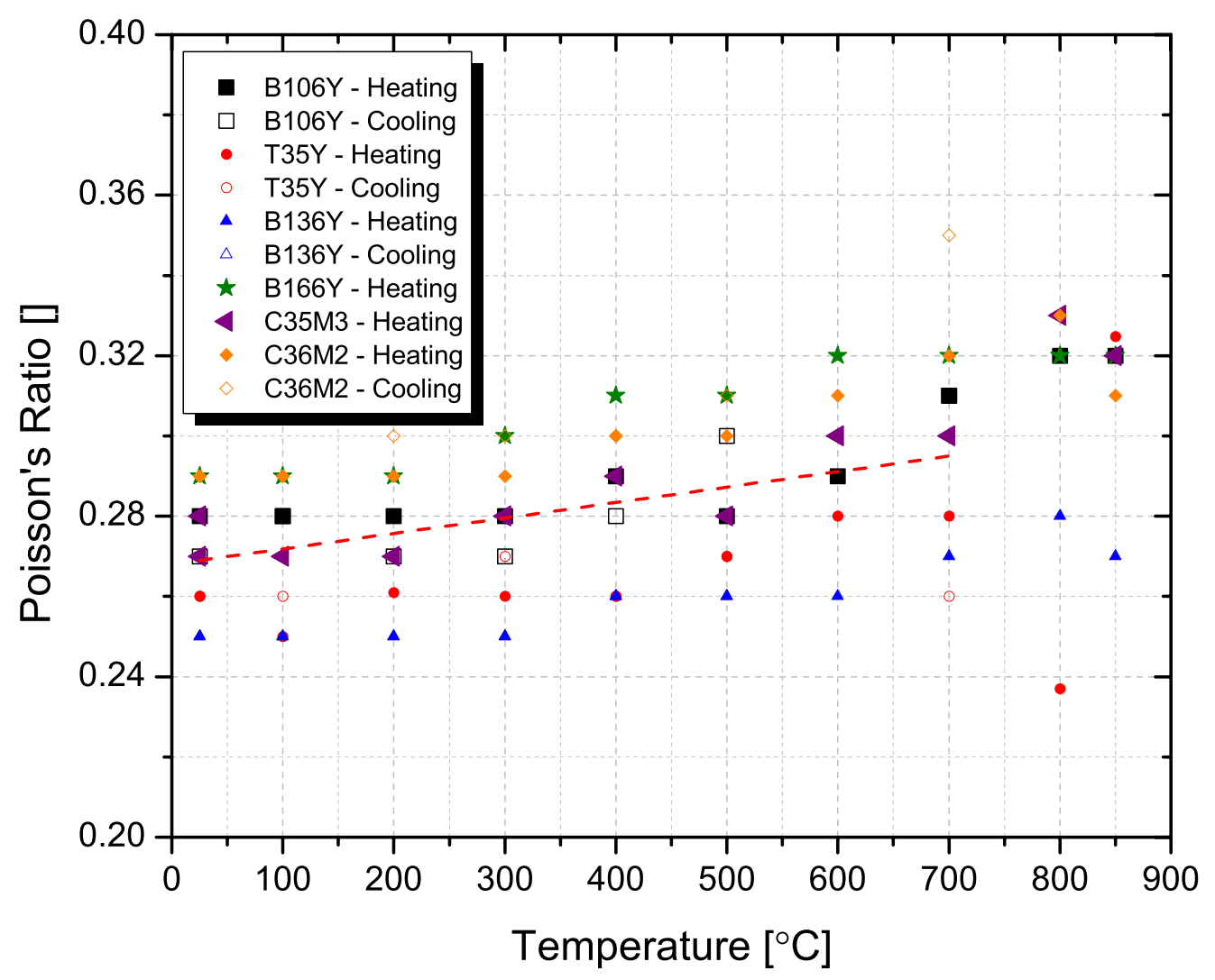

Figure 2. Poisson's ratio of the various ORNL wrought FeCrAl alloys as a function of temperature.

In case of both the elastic modulus and Poisson's ratio, very similar values are obtained during the heating and cooling curves for the various wrought $\mathrm{FeCrAl}$ alloys. High temperature annealing does not seem to affect the value of the Young's modulus, though this is expected since most of the alloys were fully annealed at $\mathrm{T}>700^{\circ} \mathrm{C}$ prior to testing. 


\section{SUMMARY}

Resonant ultrasonic spectroscopy was used to determine the elastic modulus and Poisson's ratio for the various wrought $\mathrm{FeCrAl}$ alloys produced at $\mathrm{ORNL}$ as a function of temperature. The alloys were in the fully annealed and unirradiated state. The elastic modulus of these ferritic alloys was 2.1-2.7× larger than that of $\mathrm{Zr}$-based alloys over the temperature range of this study $\left(25-850^{\circ} \mathrm{C}\right)$. This higher modulus value will enable utilization of thinner cladding that is envisioned for FeCrAl alloys. The Poisson's ratio of the alloys increased slightly with increasing temperature over this range. 


\section{REFERENCES}

[1] K. A. Terrani, S. J. Zinkle, and L. L. Snead, "Advanced oxidation-resistant iron-based alloys for LWR fuel cladding," Journal of Nuclear Materials, vol. 448, pp. 420-435, 2014.

[2] Y. Yamamoto, B. A. Pint, K. A. Terrani, K. G. Field, Y. Yang, and L. L. Snead, "Development and Property Evaluation of Nuclear Grade Wrought FeCrAl Fuel Cladding for Light Water Reactors," Journal of Nuclear Materials, vol. submitted, 2015.

[3] A. Migliori, J. Sarrao, W. M. Visscher, T. Bell, M. Lei, Z. Fisk, et al., "Resonant ultrasound spectroscopic techniques for measurement of the elastic moduli of solids," Physica B: Condensed Matter, vol. 183, pp. 124, 1993.

[4] K. J. Geelhood, C. E. Beyer, and W. G. Luscher, "PNNL Stress/Strain Correlation for Zircaloy, PNNL17700," Pacific Northwest National Laboratory2008.

[5] "Schwarzkopf Plansee PM 2000, Sheet Grain Class 6 ODS Iron Alloy Sheet, material property datasheet, Material No.: 1.4768, Abbreviated DIN name: CrAI 21 6. ."

[6] "Kanthal APM and APMT Tube Material datasheet, AB Sandvik group, Sandviken, Sweden." 


\section{Appendix A: Measured Elastic and Shear Moduli, Poisson's Ratio, and Associated Error for}

Wrought ORNL FeCrAl Alloys

\begin{tabular}{|c|c|c|c|c|c|c|c|c|c|}
\hline \multicolumn{5}{|c|}{ B106Y - Heating } & \multicolumn{5}{|c|}{$\begin{array}{r}\text { B136Y - Cooling } \\
\end{array}$} \\
\hline \begin{tabular}{|c|} 
Temperature \\
{$\left[{ }^{\circ} \mathrm{C}\right]$}
\end{tabular} & $\begin{array}{c}\text { Elastic Modulus } \\
{[\mathrm{GPa}]}\end{array}$ & $\begin{array}{c}\text { Shear Modulus } \\
\text { [GPa] }\end{array}$ & $\begin{array}{c}\text { Poisson's } \\
\text { Ratio [] }\end{array}$ & $\begin{array}{c}\text { RMS Error } \\
{[\%]}\end{array}$ & \begin{tabular}{|c} 
Temperature \\
{$\left[{ }^{\circ} \mathrm{C}\right]$}
\end{tabular} & $\begin{array}{c}\text { Elastic Modulus } \\
{[\mathrm{GPa}]}\end{array}$ & $\begin{array}{c}\text { Shear Modulus } \\
{[\mathrm{GPa}]}\end{array}$ & $\begin{array}{c}\text { Poisson's } \\
\text { Ratio [] }\end{array}$ & $\begin{array}{c}\text { RMS Error } \\
{[\%]}\end{array}$ \\
\hline 25 & 195.85 & 76.68 & 0.28 & 1.5989 & 700 & 139.73 & 54.74 & 0.28 & 1.64 \\
\hline 25 & 195.9 & 76.67 & 0.28 & 1.6203 & 500 & 165.02 & 65.68 & 0.26 & 1.91 \\
\hline 100 & 191.89 & 75.01 & 0.28 & 1.5957 & 400 & 174.2 & 69.37 & 0.26 & 1.46 \\
\hline 200 & 186.7 & 72.74 & 0.28 & 1.57 & 300 & 180.14 & 71.84 & 0.25 & 1.3 \\
\hline 300 & 181.91 & 70.82 & 0.28 & 1.61 & 200 & 185.47 & 74.34 & 0.25 & 1.17 \\
\hline 400 & 174.9 & 68.04 & 0.29 & 1.69 & 100 & 190.16 & 76.29 & 0.25 & 1.15 \\
\hline 500 & 166.6 & 65 & 0.28 & 2.72 & 25 & 193.8 & 77.83 & 0.25 & 1.13 \\
\hline 600 & 154.32 & 59.63 & 0.29 & 1.94 & \multicolumn{5}{|c|}{\begin{tabular}{|c|} 
B166Y - Heating \\
\end{tabular}} \\
\hline 700 & 141.99 & 54.35 & 0.31 & 1.52 & $\begin{array}{c}\text { Temperature } \\
{\left[{ }^{\circ} \mathrm{C}\right]}\end{array}$ & $\begin{array}{c}\text { Elastic Modulus } \\
{[\mathrm{GPa}]}\end{array}$ & $\begin{array}{c}\text { Shear Modulus } \\
{[\mathrm{GPa}]}\end{array}$ & $\begin{array}{c}\text { Poisson's } \\
\text { Ratio [] }\end{array}$ & $\begin{array}{c}\text { RMS Error } \\
{[\%]}\end{array}$ \\
\hline 800 & 131.85 & 50.07 & 0.32 & 1.85 & 25 & 201.61 & 78.02 & 0.29 & 1.02 \\
\hline 850 & 128.81 & 48.78 & 0.32 & 2.36 & 25 & 201.6 & 78.02 & 0.29 & 1.5 \\
\hline \multicolumn{5}{|c|}{ B106Y - Cooling } & 100 & 197.74 & 76.38 & 0.29 & 0.98 \\
\hline \begin{tabular}{|c|} 
Temperature \\
{$\left[{ }^{\circ} \mathrm{C}\right]$}
\end{tabular} & $\begin{array}{c}\text { Elastic Modulus } \\
\text { [GPa] }\end{array}$ & $\begin{array}{c}\text { Shear Modulus } \\
\text { [GPa] }\end{array}$ & $\begin{array}{c}\text { Poisson's } \\
\text { Ratio [] }\end{array}$ & $\begin{array}{c}\text { RMS Error } \\
{[\%]}\end{array}$ & 200 & 192.88 & 74.48 & 0.29 & 1.02 \\
\hline 700 & 143.79 & 55.02 & 0.31 & 2.04 & 300 & 186.73 & 71.76 & 0.3 & 1.05 \\
\hline 500 & 167.3 & 64.53 & 0.3 & 1.58 & 400 & 178.92 & 68.55 & 0.31 & 1.17 \\
\hline 400 & 176.64 & 69.14 & 0.28 & 2.19 & 500 & 169.24 & 64.49 & 0.31 & 1.17 \\
\hline 300 & 182.71 & 71.8 & 0.27 & 1.46 & 600 & 156 & 59.14 & 0.32 & 1.44 \\
\hline 200 & 188.4 & 73.96 & 0.27 & 1.1 & 700 & 145.52 & 54.96 & 0.32 & 1.46 \\
\hline 100 & 192.19 & 75.29 & 0.28 & 0.7 & 800 & 139.13 & 52.59 & 0.32 & 2.88 \\
\hline 25 & 196.13 & 77.08 & 0.27 & 0.76 & 850 & 138.09 & 52.46 & 0.32 & 3.3 \\
\hline \multicolumn{5}{|c|}{ T35Y - Heating } & \multicolumn{5}{|c|}{ C35M3 - Heating } \\
\hline \begin{tabular}{|c|} 
Temperature \\
{$\left[{ }^{\circ} \mathrm{C}\right]$}
\end{tabular} & $\begin{array}{c}\text { Elastic Modulus } \\
{[\mathrm{GPa}]}\end{array}$ & $\begin{array}{c}\text { Shear Modulus } \\
\text { [GPa] }\end{array}$ & $\begin{array}{l}\text { Poisson's } \\
\text { Ratio [] }\end{array}$ & $\begin{array}{c}\text { RMS Error } \\
{[\%]}\end{array}$ & $\begin{array}{c}\text { Temperature } \\
{\left[{ }^{\circ} \mathrm{C}\right]}\end{array}$ & $\begin{array}{c}\text { Elastic Modulus } \\
{[\mathrm{GPa}]}\end{array}$ & $\begin{array}{c}\text { Shear Modulus } \\
{[\mathrm{GPa}]}\end{array}$ & $\begin{array}{c}\text { Poisson's } \\
\text { Ratio [] }\end{array}$ & $\begin{array}{c}\text { RMS Error } \\
{[\%]}\end{array}$ \\
\hline 25 & 195.64 & 77.48 & 0.26 & 2.7262 & 25 & 203.65 & 79.27 & 0.28 & 2.36 \\
\hline 25 & 195.70 & 77.8 & 0.26 & 1.0453 & 25 & 205.13 & 80.86 & 0.27 & 2.11 \\
\hline 100 & 188.57 & 75.17 & 0.25 & 1.3854 & 100 & 201.33 & 79.23 & 0.27 & 2.15 \\
\hline 200 & 187.74 & 74.44 & 0.26 & 1.1225 & 200 & 195.63 & 76.78 & 0.27 & 2.21 \\
\hline 300 & 182.01 & 72.28 & 0.26 & 1.1094 & 300 & 188.98 & 74 & 0.28 & 2.27 \\
\hline 400 & 175.05 & 69.6 & 0.26 & 1.2833 & 400 & 181.57 & 70.26 & 0.29 & 2.66 \\
\hline 500 & 164.13 & 64.84 & 0.27 & 1.2149 & 500 & 171.96 & 67.06 & 0.28 & 2.41 \\
\hline 600 & 149.52 & 58.61 & 0.28 & 1.5751 & 600 & 158.15 & 60.65 & 0.3 & 2.92 \\
\hline 700 & 136.89 & 53.6 & 0.28 & 1.4579 & 700 & 148.87 & 57.05 & 0.3 & 3.92 \\
\hline 800 & 127.98 & 51.73 & 0.24 & 2.6234 & 800 & 138.32 & 52.06 & 0.33 & 4.83 \\
\hline 850 & 119.68 & 45.17 & 0.32 & 3.4268 & 850 & 133.98 & 50.88 & 0.32 & 4.78 \\
\hline
\end{tabular}




\begin{tabular}{|c|c|c|c|c|c|c|c|c|c|}
\hline \multicolumn{5}{|c|}{ T35Y - Cooling } & \multicolumn{5}{|c|}{ C36M2 - Heating } \\
\hline $\begin{array}{c}\text { Temperature } \\
{\left[{ }^{\circ} \mathrm{C}\right]}\end{array}$ & $\begin{array}{c}\text { Elastic Modulus } \\
{[\mathrm{GPa}]}\end{array}$ & $\begin{array}{c}\text { Shear Modulus } \\
\text { [GPa] }\end{array}$ & $\begin{array}{l}\text { Poisson's } \\
\text { Ratio [] }\end{array}$ & $\begin{array}{c}\text { RMS Error } \\
{[\%]}\end{array}$ & $\begin{array}{c}\text { Temperature } \\
{\left[{ }^{\circ} \mathrm{C}\right]}\end{array}$ & $\begin{array}{c}\text { Elastic Modulus } \\
\text { [GPa] }\end{array}$ & $\begin{array}{c}\text { Shear Modulus } \\
\text { [GPa] }\end{array}$ & $\begin{array}{l}\text { Poisson's } \\
\text { Ratio [] }\end{array}$ & $\begin{array}{c}\text { RMS Error } \\
{[\%]}\end{array}$ \\
\hline 700 & 138.94 & 55.29 & 0.26 & 2.3 & 25 & 200.91 & 77.9 & 0.29 & 2.38 \\
\hline 500 & 164.28 & 64.87 & 0.27 & 1.38 & 25 & 200.79 & 77.96 & 0.29 & 2.44 \\
\hline 400 & 174.39 & 69.02 & 0.26 & 1.07 & 100 & 196.67 & 76.23 & 0.29 & 2.44 \\
\hline 300 & 181.42 & 71.63 & 0.27 & 1.07 & 200 & 191.75 & 74.06 & 0.29 & 2.45 \\
\hline 200 & 187.39 & 74.04 & 0.27 & 1.04 & 300 & 186.54 & 72.11 & 0.29 & 2.42 \\
\hline 100 & 192.08 & 76.14 & 0.26 & 1.1 & 400 & 180.61 & 69.59 & 0.3 & 2.74 \\
\hline 25 & 195.25 & 77.45 & 0.26 & 0.98 & 500 & 169.43 & 64.95 & 0.3 & 2.77 \\
\hline \multicolumn{5}{|c|}{ B136Y - Heating } & 600 & 157.06 & 59.9 & 0.31 & 3.03 \\
\hline $\begin{array}{c}\text { Temperature } \\
{\left[{ }^{\circ} \mathrm{C}\right]}\end{array}$ & $\begin{array}{c}\text { Elastic Modulus } \\
\text { [GPa] }\end{array}$ & $\begin{array}{c}\text { Shear Modulus } \\
{[\mathrm{GPa}]}\end{array}$ & $\begin{array}{l}\text { Poisson's } \\
\text { Ratio [] }\end{array}$ & $\begin{array}{c}\text { RMS Error } \\
{[\%]}\end{array}$ & 700 & 146.32 & 55.35 & 0.32 & 3.46 \\
\hline 25 & 194.39 & 77.68 & 0.25 & 1.12 & 800 & 137.79 & 51.74 & 0.33 & 4.64 \\
\hline 25 & 194.36 & 77.84 & 0.25 & 1.15 & 850 & 132.89 & 50.84 & 0.31 & 4.31 \\
\hline 100 & 190.79 & 76.28 & 0.25 & 1.14 & \multicolumn{5}{|c|}{ C36M2 - Cooling } \\
\hline 200 & 185.6 & 74.12 & 0.25 & 1.18 & $\begin{array}{c}\text { Temperature } \\
{\left[{ }^{\circ} \mathrm{C}\right]}\end{array}$ & $\begin{array}{c}\text { Elastic Modulus } \\
{[\mathrm{GPa}]}\end{array}$ & $\begin{array}{c}\text { Shear Modulus } \\
\text { [GPa] }\end{array}$ & $\begin{array}{c}\text { Poisson's } \\
\text { Ratio [] }\end{array}$ & $\begin{array}{c}\text { RMS Error } \\
{[\%]}\end{array}$ \\
\hline 300 & 180.62 & 72.13 & 0.25 & 1.24 & 700 & 144.42 & 53.43 & 0.35 & 3.84 \\
\hline 400 & 172.78 & 68.8 & 0.26 & 1.23 & 500 & 169.35 & 64.64 & 0.31 & 4.11 \\
\hline 500 & 163.6 & 64.99 & 0.26 & 1.27 & 400 & 179.73 & 68.9 & 0.3 & 3.78 \\
\hline 600 & 150.91 & 59.75 & 0.26 & 1.36 & 300 & 187.56 & 72.19 & 0.3 & 3.59 \\
\hline 700 & 139.5 & 55.05 & 0.27 & 1.61 & 200 & 193.73 & 74.76 & 0.3 & 3.48 \\
\hline 800 & 131.46 & 51.38 & 0.28 & 1.93 & 100 & 198.42 & 76.7 & 0.29 & 3.41 \\
\hline 850 & 126.02 & 49.72 & 0.27 & 2.3 & 25 & 202.29 & 78.34 & 0.29 & 3.35 \\
\hline
\end{tabular}


